\title{
Nursing education in Poland
}

\author{
Kształcenie w zawodzie pielęgniarki w Polsce
}

\section{Karolina Pradela', Zuzanna Radosz², Agnieszka Sobiegała ${ }^{3}$}

\author{
${ }^{1}$ Hospital of the Brothers Hospitallers of St. John of God in Katowice/ \\ Szpital Zakonu Bonifratrów pw. Aniołów Stróżów w Katowicach \\ 2Postgraduate student, Faculty of Health Sciences, Jagiellonian University Medical College/ \\ Uczestnik studiów III stopnia, Wydział Nauk o Zdrowiu UJ CM Kraków Guardian Angels \\ ${ }^{3}$ Department of Pedagogy, The School of Health Sciences in Katowice, The Medical University of Silesia/ \\ Zakład Pedagogiki, Wydział Nauk o Zdrowiu w Katowicach, Śląski Uniwersytet Medyczny w Katowicach \\ Karolina Pradela: 0000-0002-9451-4437 \\ Zuzanna Radosz: 0000-0001-8371-6845 \\ Agnieszka Sobiegała: 0000-0003-3323-8384 \\ CORRESPONDING AUTHOR/AUTOR DO KORESPONDENCJ: \\ Zuzanna Radosz \\ Instytut Pielęgniarstwa i Położnictwa UJ CM \\ ul. Kopernika 25, 31-501 Kraków \\ e-mail: radosz.zuzanna@gmail.com
}

\section{STRESZCZENIE}

Słowa kluczowe:

\section{ABSTRACT}

Key words:

\section{KSZTAKCENIE W ZAWODZIE PIELĘGNIARKI W POLSCE}

Cel pracy. Celem pracy była analiza piśmiennictwa dotycząca kształcenia w zawodzie pielęgniarki w Polsce, ze szczególnym uwzględnieniem obecnego kształcenia oraz kształcenia w liceach medycznych i medycznych studiach zawodowych na poziomie średnim w zakresie podstawowym.

Materiał i metody. Przegląd piśmiennictwa oraz analiza dokumentów (świadectw, indeksu nauczania) z zakresu kształcenia w zawodzie pielęgniarki w Polsce.

Omówienie. Początkowo rolę pielęgniarek pełniły osoby duchowne lub świeckie w ramach wolontariatu, osoby niewykształcone i nieprzygotowane do pracy w zawodzie, zarówno teoretycznie jak i praktycznie, aż zaczęto kształcić w tej dziedzinie i zawodem tym zaczęły się zajmować osoby wykwalifikowane. Kształcenie w dziedzinie pielęgniarstwa zmieniało formę przez lata. Pierwsze ujednolicenie systemu kształcenia pielęgniarstwa nastąpiło w 1961 r., a kolejne wraz z wprowadzeniem Procesu Bolońskiego z 2000 roku. Podsumowanie. W pracy zwrócono uwagę na różnice w przebiegu kształcenia w zawodzie pielęgniarki i pielęgniarza w okresie od XVIII wieku do czasów współczesnych. Kształcenie w zawodzie pielęgniarza i pielęgniarki przez wiele lat zmieniało formę. Osoby aktualnie pracujące w tym zawodzie posiadają różne poziomy wykształcenia od średniego, aż po wyższe.

pielęgniarstwo, edukacja, Polska

Aim. The aim of the study was to analyse the literature concerning nursing education in Poland, with particular emphasis on current education and the Medical High School and Medical Vocational College at the secondary level in the basic range.

Material and methods. Literature review and analysis of documents (certificates, teaching index) in the field of nursing education in Poland.

Results. Initially, the role of nurses was played by the clergy or volunteers, by people who lacked both theoretical and practical knowledge to work in the profession, until the professional training began and qualified persons started to practice the profession. Nursing has been changing its form for many thousands of years. The first unification of the nursing education system took place in 1961, followed by the introduction of the Bologna Process in 2000.

Conclusions. This thisis points to the differences between the courses of nursing education in a period from $18^{\text {th }}$ century until today. Nursing education has changed its form for many years. Today, professional nurses have different levels of education, from secondary to higher education.

Nursing, education, Poland 


\section{INTRODUCTION}

The nursing profession has historically been underestimated in Poland, but has gained more recognition in recent years. In the 2019 competition rankings made by the CBOS, the nurse ranks high second position, right behind after the fireman [1]. It is suggested that this is due to raising the qualifications of nurses, and more specifically university education [2].

The level of education of nurses is varied. The development of nursing education in Poland was affected by the social, political and economic situation, as well as foreign influence [1]. Initially, the education had the form of training courses until the emergence of schools for clergymen and lay people [2].

This profession is practised by persons with different levels of education. Among the professionally active nurses there are persons with secondary education (persons, who graduated from secondary medical schools), post-secondary education (vocational studies), as well as higher education (bachelor and master studies) [3].

Currently, teaching of nursing is based on the European Union standards from 2000 (the so-called Bologna Process guidelines) and is standardized throughout the country - to obtain the right to practice the profession of a nurse first degree studies in nursing should be completed $[4,5]$. It is possible to continue education in this field at master studies and even obtain the academic degree of doktor (Ph.D.), doktor habilitowany (habilitated Ph.D.) or professor [6].

Research done by Kózka et al. in 2007 shows that nursing education has undergone a transformation process, it has influenced the qualifications of nurses and their image. Nurses' motivation to continuing professional development also affects the professional competence of nurses [7].

\section{AIM}

The aim of the study was to analyze the literature on nursing education in Poland, with particular emphasis on current education and education in medical high schools and medical vocational studies at the secondary level in the basic range.

\section{MATERIAL AND METHODS}

Literature review and analysis of documents (certificates, teaching index) in the field of nursing education in Poland.

This article deals with the analysis of literature on nursing education starting from the $18^{\text {th }}$ century until modern times.

\section{RESULTS}

\section{Nursing education in Poland in the basic range since $18^{\text {th }}$ century}

Education is a planned, purposeful and regular process aimed at obtaining specific skills and abilities [8]. It allows people to acquire and develop interests, knowledge and qualifications [8].

Ciechaniewicz [8] defines education as completion of general education, i.e. education aimed at acquiring practical knowledge on nature, society and their development, as well as vocational education, which encompasses practical and theoretical knowledge in a specific field. Therefore, education means formal knowledge gained in accordance with prescribed standards and confirmed by a relevant document. Education allows people to know the world and find their place in it or allows them to practice their acquired profession [9]. Nursing has developed over the centuries along with the need to care for the sick. There have been many changes in the nursing profession, education and nursing law [10]. For many years, various persons and institutions have dealt with the care for the sick children, adults and elderly [3].

In the Middle Ages, religious organisations were responsible for taking care of the sick, e.g. the Cistercian order, which founded hospitals in Wrocław (1108) and Jędrzejów (1152) [11]. In Poland, initially the care for the people in need was provided by sisters and brothers from various religious orders [11]. Over the years, the nature of nursing has changed. The key moment in the development of nursing profession was the establishment of the first school responsible for the education of lay nurses in London [5] by Florence Nightingale, who is considered to be the pioneer of nursing [12]. This marked the beginning of professional nursing. Florence Nightingale gave an example for the whole world. A Caretaker School was established in Lviv in year 1895, which was later transformed into the Nursing School $[4,13]$. The school prepared nuns and laypeople to practise as a nurse. Schools in Krakow (1925), Warsaw (1921) and Poznań (1921) were also established [4, 12, 14].

The University School of Nurses and Health Caregivers (Hygienists) operated in Krakow - in short, USPiH. The school was organized by the creators and graduates of the School of Professional Nurses of the PP Association of St. Economist Vincent de Paul, which was enjoyed by the acceptance of the medical community and the support of professors of the Jagiellonian University. As the only one in Poland (at that time) it operated within the Faculty of Medicine at the Jagiellonian University. The school educated in the basic range, but had an autonomous study and its own statute. The University School of Nurses was the first Polish nursing school run from the very beginning exclusively by Polish nurses. Schools in Warsaw (Warsaw School of Nursing) and Poznań (Polish Red Cross School of Nursing) were run by American women - in Warsaw by Helen Bridge (American, delegated by the International Red Cross to establish education for secular nurses in Poland) and in Poznań by Ita Mac Donell (brought to Poland by the American Red Cross) [15].

At the end of the $19^{\text {th }}$ century, the International Council of Nurses was established, which started the era of education of licensed nurses - which was also the beginning of the development of Polish nursing. The following organisations were engaged in the development of nursing in Poland: the International Red Cross Organisation, the American Red Cross Organization and the Rockefeller 
Foundation and licensed nurses from abroad, mainly from the United States. The Rockefeller Foundation's financial support enabled Polish nurses to go abroad for scholarships. Scholarship trips to the countries of North America and Western Europe allowed for updating knowledge and raising professional qualifications $[10,15,16]$.

During the World War II, the whole education system collapsed, including nursing, the occupier agreed to educate nurses only at the school in Warsaw, the number of people who gained this profession dropped significantly $[10,14$, 16]. The Warsaw School of Nursing operated until the outbreak of the Warsaw Uprising, i.e. until August 1, 1944. After the war, it was necessary to fill in the gaps among nurses, and therefore, admission to the profession was allowed through courses lasting several months - in total there were 13 possibilities to become a nurse. In 1945, the nursing school in Krakow resumed - USPiH. A school was established in Gdańsk (1945), and in Warsaw at the Main Board of the Trade Union of Health Care Workers (1947). The number of schools increased rapidly $[15,17]$.

Then came the times of Communist Poland, where education was varied. Until the 1950s, pre-war education systems were followed. Nursing Assistant schools, secondary medical schools and post-secondary schools were established $[3,9,10]$. One of the milestones in the development of nursing in Poland was the establishment of the Polish Association of Vocational Nurses (1925) and the Polish Nurses' Association in 1957. It led to harmonisation of education in this field (Act on the development of education system of 15 July 1961) [18]. Thanks to the activities of the Polish Nursing Association, it was possible to establish a three-year nurse education at the Medical Academy in Lublin (1969) and to create a Nursing Faculty there, which initiated cooperation with the World Health Organization (WHO) [19]. At that time, the following schools were established: state general nursing schools 2 years after graduation, 2 and half-years state schools of neuropsychiatric nursing after completing 9 classes of elementary school, 5-years medical high schools nursing after graduating 7 years of primary school, 4-years medical high schools nursing after graduation 9 classes of primary school, 3-year medical nursing high schools for working nursing assistants [20].

Among professionally active male and female nurses, the lowest level of education is secondary medical school [13]. Initially, the education in a secondary school lasted 4 years and, since 1965, 5 years [8, 10, 16]. Nursing was taught in secondary medical schools until the early 1990s, when it was decided to close those schools and to start teaching the profession only in post-secondary schools.

The establishment of Medical Vocational Studies enabled the teaching of the profession after graduating from high school (until 1981, candidates were required to obtain a secondary school-leaving certificate). From 1991/1992, five-year nursing schools stopped enrolling students [11]. In 1993, in connection with the planned accession of Poland to the EU, a change in the education system in the profession of nurse and midwife began to adapt Polish law to the EU directives [21]. This led to the establishment of several other nursing faculties at medical academies/universities: in Łódź (1997), Bydgoszcz (1998), Gdańsk (1999), Białystok (1999), Warsaw (2000) and Szczecin (2001). Newly established academic units offered master's programs for candidates who completed nursing studies after completing the basic stage of education [22].

\section{Current nursing education on the basic range in Poland}

Polish nursing is constantly changing in the field of nurse education. Today's nursing in Poland is ambitious and dynamically developing.

Currently, the title of nurse can be obtained by: graduating from three-year bachelor studies (first-cycle studies) in the field of nursing [23]. Continuous education and development is a part of the duty of a nurse. In this profession, it is necessary to update one's knowledge constantly $[4,23]$. It is possible to continue education at second-cycle studies - master's studies and third-cycle studies - Ph.D. studies. Another stage of professional development is postgraduate education in the form of specialty courses, qualification courses, specialist courses or additional trainings $[23,24]$. Postgraduate education is available to every nurse regardless of her/his level of education. In accordance with the art. 67 clause 1 of the Act of 15 July 2011 on the Profession of Nurse and Obstetrician - Official Journal of 2018, item 123 as amended - [4] a nurse can obtain the title of nursing specialist by attending a specialist course ending with a state exam. The title of nursing specialist [25] is obtained by completing a specialist training lasting from 15 to 20 months, whose goal is to teach specialist knowledge and skills to nurses in a specific field of nursing.

In order to be conferred the vocational degree of nurse, it is necessary to complete bachelor studies. According to the Polish standards, education in the field of nursing and obstetrics at bachelor studies should last at least 6 semesters (3 years).The number of hours of practical classes together with vocational training should be at least 4720 and the number of ECTS points should be at least 180 [23].

First-cycle studies encompass education in the following areas [23]:

- basic sciences: anatomy, physiology, pathology, genetics, biochemistry and biophysics, microbiology and parasitology, pharmacology, radiology;

- social sciences and humanities: psychology, sociology, pedagogy, medical law, public health, English;

- basic nursing care sciences: fundamentals of nursing, nursing ethics, health promotion, primary health care, nutrition, nursing work organisation, physical examination, hospital infections, healthcare information system, optional courses to choose from: sign language or cooperation in health care centres;

- specialist care sciences: internal diseases and internist nursing, pediatrics and pediatric nursing, surgery and surgical nursing, obstetrics, gynecology and gynecological-obstetric nursing, anesthesiology and nursing in life-threatening conditions, long-term nursing care, neurology and neurological nursing, geriatrics and geriatric nursing, palliative care, fundamentals of rehabilitation, fundamentals of first aid, nursing research, diploma seminar. 
Bachelor studies in the field of nursing end with a diploma exam (both theory and practice), as well as writing a diploma thesis $[8,23,24]$.

\section{Differences in education}

Nursing education has changed its form over the years. Courses taught in secondary medical schools, medical vocational studies, post-secondary schools or bachelor studies were different from one another. Courses taught in secondary medical schools differed from the courses currently taught at bachelor studies, what is more, they were different in different secondary schools (Table 1). Courses such as: psychology, pedagogy and sociology which are taught at bachelor studies as separate courses were combined into one course in secondary medical schools: fundamentals of psychology, pedagogy and sociology and in some secondary schools, the course included only psychology and pedagogy without sociology. Specialist care education is also varied. The scope of specialist knowledge was much limited in comparison with the current knowledge. Courses in basic sciences were also not the same in various secondary schools, they differ greatly from the courses taught today at first-cycle studies. It did not include education in: physiology - this was only one course:
Anatomy, Physiology and Parasitology. Subjects that were not taught in every secondary school: genetics, biochemistry and biophysics, microbiology - microbiology was taught as part of biology with microbiology courses, but not in every school, as well as radiology.

Education as part of Medical Vocational Studies (Tab. 2), similarly to secondary medical schools, was far from the current educational standards regarding social sciences. Courses such as psychology or sociology were included in the curriculum, however, they did not encompass education in the area of pedagogy, public health, philosophy or nursing ethics. Nutrition was not taught, in secondary medical schools the name of the course was Hygiene and Nutrition. Similarly to secondary medical schools, the curriculum did not include parasitology, genetics, biochemistry or biophysics. However, students were taught microbiology, law and Latin.

In his paper, Klapa [28] points to the modification of humanities education in the field of nursing, mainly pedagogy, which had not been taught before nursing was introduced to universities. The role of the nurse is not only caretaking and nursing. Duties of the nurse also include health promotion, health education, work with young people, conducting courses and trainings, as well as supporting

Tab. 1. List of subjects taught in secondary medical schools in the years 1984-1989 on the example of the Secondary Medical School in Tychy and in the years 1980-1985 on the example of the Secondary Medical School in Katowice [26]

\begin{tabular}{|c|c|c|}
\hline Scope of education & \begin{tabular}{|l} 
List of courses \\
(on the example of the Secondary Medical School in Tychy)
\end{tabular} & $\begin{array}{l}\text { List of courses } \\
\text { (on the example of the Secondary Medical School in Katowice) }\end{array}$ \\
\hline Basic sciences & $\begin{array}{l}\text { - anatomy and physiology, } \\
\text { - drug sciences, } \\
\text { - pathology, } \\
\text { - biology with microbiology, }\end{array}$ & $\begin{array}{l}\text { - anatomy, } \\
\text { - introduction to drug sciences, } \\
\text { - pathology, }\end{array}$ \\
\hline Social sciences & $\begin{array}{l}\text { - fundamentals of psychology, pedagogy and sociology; } \\
\text { - psychology; }\end{array}$ & $\begin{array}{l}\text { - psychology and pedagogy, } \\
\text { - psychology, }\end{array}$ \\
\hline Basic nursing care sciences & $\begin{array}{l}\text { - general nursing } \\
\text { - nursing room; } \\
\text { - hygiene and nutrition; } \\
\text { - infectious diseases; } \\
\text { - skin diseases and STDs; } \\
\text { - professional issues, }\end{array}$ & $\begin{array}{l}\text { - general nursing, } \\
\text { - nursing room, } \\
\text { - nursing exercises, } \\
\text { - nutrition hygiene with exercises, } \\
\text { - infectious diseases, } \\
\text { - skin diseases and STDs, } \\
\text { - health care organisation, } \\
\text { - professional issues, } \\
\text { - general hygiene, school hygiene, industrial hygiene, }\end{array}$ \\
\hline Basic specialist care sciences & $\begin{array}{l}\text { - internal diseases; } \\
\text { - surgery, transplantation and immediate aid, } \\
\text { - nursing in internal diseases, } \\
\text { - modular practical classes, } \\
\text { - surgery, transfusion and immediate aid; } \\
\text { - developmental age medicine; } \\
\text { - obstetrics and women's diseases, } \\
\text { - nervous and mental disorders, } \\
\text { - surgical nursing, } \\
\text { - obstetric and gynecological nursing, } \\
\text { - open treatment nursing, } \\
\text { - neurological nursing, } \\
\text { - neurology, }\end{array}$ & $\begin{array}{l}\text { - modular practical classes, } \\
\text { - nursing in surgical diseases, } \\
\text { - obstetric nursing, } \\
\text { - surgery, } \\
\text { - child nursing, } \\
\text { - pediatrics, } \\
\text { - obstetrics and gynecology, } \\
\text { - nervous and mental disorders, } \\
\text { - psychiatry, } \\
\text { - neuropsychiatric nursing, } \\
\text { - internal medicine, } \\
\text { - internal nursing, } \\
\text { - nursing in open health care, }\end{array}$ \\
\hline Foreign language & $\begin{array}{l}\text { - Latin, } \\
\text { - Russian, }\end{array}$ & $\begin{array}{l}\text { - Latin, } \\
\text { - German. }\end{array}$ \\
\hline
\end{tabular}

Own elaboration based on: School certificates of the Secondary Medical School in Tychy from the years 1984-1989 and school certificates of the Secondary Medical School in Katowice from the years 1980-1985 [27]. 
patients and their families psychologically and pedagogically [28]. The nurse stays with the patient on an ongoing basis, therefore it is necessary to possess humanities and social sciences knowledge, such as andragogy, pedagogy, psychology and sociology [29]. It may be concluded that nurses who graduated from bachelor nursing studies are better prepared for the job than nurses who pursued their education in previous years. Nurses with a professional degree of master in nursing should be the best prepared for their role.

As part of education in previous education systems (i.e. Medical High School, Medical Vocational Studies) in the field of nursing, more attention was paid to the appearance of candidates for nurses. Schoolgirls could not have painted nails, hair had to be pinned, uniforms all schoolgirls in one class had to look the same, in addition it was necessary to wear a nursing cap [30]. There are currently no requirements for uniforms, and wearing a shower cap is not mandatory.

Tab. 2. List of courses taught in the years 1990-1992 on the example of the Vocational Medical Studies No. 3 in Katowice [31]

\begin{tabular}{|c|c|}
\hline Scope of education & List of courses \\
\hline Basic sciences & $\begin{array}{l}\text { - pharmacology, } \\
\text { - microbiology, } \\
\text { - anatomy, } \\
\text { - pathology, }\end{array}$ \\
\hline Social sciences & $\begin{array}{l}\text { - sociology, } \\
\text { - psychology, } \\
\text { - hygiene and safety, labour law }\end{array}$ \\
\hline Basic nursing care sciences & $\begin{array}{l}\text { - } \text { skin diseases and STDs, } \\
\text { - general nursing, } \\
\text { - nursing room, } \\
\text { - health care organisation } \\
\text { - hygiene and safety, labour law } \\
\text { - nursing in open health care, }\end{array}$ \\
\hline Basic specialist care sciences & $\begin{array}{l}\text { - internal diseases; } \\
\text { - internal nursing, } \\
\text { - surgery, } \\
\text { - surgical nursing, } \\
\text { - nervous and mental disorders, } \\
\text { - neurological and psychological nursing, } \\
\text { - obstetrics and women's diseases, } \\
\text { - developmental age medicine, } \\
\text { - obstetric and gynecological nursing, }\end{array}$ \\
\hline Foreign language & - Latin. \\
\hline
\end{tabular}

Own elaboration based on: Student's Record Book of the Vocational Medical Studies No. 3 in Katowice from the years:1990-1992 [31]

Nursing education has changed throughout the years. The differences include the level of education: secondary, post-secondary, higher education; duration of education in the field of nursing, as well as duration of previous education. Education in a secondary medical school lasted 5 years and included general education together with professional education $[6,23]$. Education in a post-secondary school lasted: $2 ; 2.5$ or 3 years $[13,14]$. Currently, education must last at least 3 years (6 semesters). Differences also concern the number of hours of education. Currently, there is a minimum of 4720 hours [23]. In the years of nursing education at secondary level, the number of hours varied from: 4256 to 3078 depending on the year. At post-secondary level (three-year), it was 4344 hours. Lasting 2 -year education at postsecondary level had the smallest number of hours $[13,14]$.

The number of hours of theory education at the level of secondary schools, vocational studies and bachelor studies is similar. It differs between 2 and 2.5-year schools. Practical education (vocational training, clinical classes, practical classes) were also different in different education systems. In secondary medical school, it ranged from 2242 to 1715 hours. As part of vocational medical studies, it ranged from 1400 to 1715 hours $[25,28]$. Currently, the total number of hours of practical classes together with vocational training at first-cycle studies is 2300 [14].

The differences in the education programs that were in force in different years are visible on the example of bridging studies - supplementary undergraduate studies. They aimed to supplement the education of nurses and enable them to obtain a bachelor's degree. This applies to nurses who have obtained the title of nurse by graduating from schools with a different specificity. A necessary condition for admission to bridging studies was having a high school diploma. The program of complementary studies depended on the year and type of school completed $[5,8]$. Nurses who have higher education (undergraduate or graduate) more appreciate and understand their professional autonomy. They also see greater opportunities in achieving professional development that has an impact on improving patient care [32].

Funding from the European Union grants gives great opportunities for the development of Polish nursing. It is also possible to receive scientific grants. The European Rancare COST project is such an example [33]. It is also worth paying attention to the general development of medicine, and thus nursing. Modern hospitals, e-health are elements that also influence the direction of development of nursing and vocational training of nurses [26].

When it comes to the development of Polish nursing, "far-sighted" thinking and management is necessary as highlighted by leaders [34]. It is important to develop a research strategy in nursing, which translates into the quality of education and has far-reaching effects [35].

\section{CONCLUSIONS}

1. Over the years, the basic system of training nurses has changed a lot.

2. Nurses' knowledge and their professional independence have increased.

3. The emphasis is still on practical vocational training. 


\section{Kształcenie w zawodzie pielęgniarki w Polsce}

\section{WPROWADZENIE}

Zawód pielęgniarki był historycznie niedoceniany w Polsce, ale w ostatnich latach zyskał większe uznanie. W rankingu poważania zawodów CBOS z 2019 roku pielęgniarka zajmuje wysokie drugie miejsce, zaraz po strażaku [1]. Sugeruje się, iż jest to spowodowane podniesieniem kwalifikacji pielęgniarek, a dokładniej wykształceniem uniwersyteckim [2].

Wpływ na rozwój kształcenia w dziedzinie pielęgniarstwa w Polsce miała sytuacja społeczna, polityczna, ekonomiczna oraz sytuacja w pielęgniarstwie światowym [1] Początkowo kształcenie odbywało się w formie kursów, aż zaczęły pojawiać się szkoły dla osób duchownych i świeckich [2].

Zawód ten wykonują osoby ze zróżnicowanym wykształceniem. Wśród aktywnych zawodowo pielęgniarek są osoby z wykształceniem średnim (osoby, które ukończyły licea medyczne), policealnym (studium zawodowe) oraz wyższym (co najmniej na poziomie licencjackim) [3].

Obecnie nauczanie pielęgniarstwa opiera się na standardach Unii Europejskiej z 2000 roku (tzw. wytyczne Procesu Bolońskiego) i jest ujednolicone w całym kraju - aby uzyskać prawo wykonywania zwodu pielęgniarki należy ukończyć studia I stopnia - licencjackie na kierunku pielęgniarstwo $[4,5]$. Możliwa jest dalsza edukacja na tym kierunku w ramach studiów drugiego stopnia (magisterskich) - to chyba do usunięcia [6].

Przeprowadzone badania przez Kózkę i wsp. w 2007 roku pokazują, że edukacja pielęgniarstwa przeszła proces transformacji, wpłynął kwalifikacje pielęgniarek i ich wizerunek. Na podniesienie kompetencji zawodowych pielęgniarek ma również wpływ motywacja pielęgniarek do ustawicznego rozwoju zawodowego [7].

\section{CEL PRACY}

Celem pracy była analiza piśmiennictwa dotycząca kształcenia w zawodzie pielęgniarki w Polsce, ze szczególnym uwzględnieniem obecnego kształcenia oraz kształcenia w liceach medycznych i medycznych studiach zawodowych na poziomie średnim w zakresie podstawowym.

\section{MATERIAŁY I METODY}

Przegląd piśmiennictwa oraz analiza dokumentów (świadectw, indeksu nauczania) z zakresu kształcenia w zawodzie pielęgniarki w Polsce.

Autorzy artykułu przeanalizowali piśmiennictwo dotyczące zagadnienia kształcenia w zawodzie pielęgniarki począwszy od XVIII wieku aż do czasów współczesnych.

\section{OMÓWIENIE}

\section{Nauczanie pielęgniarstwa w zakresie podstawowym w Polsce od XVIII wieku}

Kształcenie to proces, który jest zaplanowany, celowy i regularny oraz umożliwia zdobycie konkretnych umiejętności i postaw [8]. Pozwala na zdobycie oraz rozwój zainteresowań, wiedzy, kwalifikacji [8].

Ciechaniewicz [8] definiuje wykształcenie jako ukończenie kształcenia ogólnego, czyli ukierunkowanego na zdobycie praktycznej wiedzy o przyrodzie, społeczeństwie i ich rozwoju oraz zawodowego, które obejmuje wiedzę praktyczno - teoretyczną w jakiejś dziedzinie. Zatem wykształcenie jest to formalna wiedza zdobyta zgodnie z obowiązującymi normami, potwierdzona odpowiednim dokumentem. Umożliwia poznanie świata i odnalezienie się w nim lub daje możliwość wykonywania wyuczonego zawodu [9]. Pielęgniarstwo kształtowało się na przestrzeni wieków wraz z koniecznością opieki nad osobami chorymi. Następowało wiele zmian w sposobie wykonywania zawodu pielęgniarki, szkolnictwie i prawie o tym zawodzie [10]. Przez lata różne osoby i organizacje zajmowały się opieką nad chorymi dziećmi, dorosłymi, a także osobami w wieku podeszłym [3].

W średniowieczu za pielęgnowanie chorych odpowiedzialne były organizacje religijne, np. zakon cysterski, który założył szpitale we Wrocławiu (1108 r.) i Jędrzejowie (1152 r.) [11]. Początkowo opiekę nad potrzebującymi w Polsce sprawowały, w formie wolontariatu, siostry i bracia zakonni z różnego rodzaju zgromadzeń [11]. Przez lata zmieniał się charakter pielęgnacji nad chorymi. Za moment kluczowy w rozwoju zawodu pielęgniarki i pielęgniarza uznaje się założenie w Londynie pierwszej szkoły odpowiedzialnej za edukację świeckich pielęgniarek [9], przez Florencję Nightingale uznawaną za prekursorkę pielęgniarstwa [12]. Był to początek profesjonalnego pielęgniarstwa. W jej ślady poszedł cały świat. We Lwowie w 1895 r. powstała Szkoła Dozorczyń, którą później przekształcono w Szkołę Pielęgniarstwa [10, 13]. Przygotowywała ona zakonnice i osoby świeckie teoretyczno - praktycznie do wykonywania zawodu pielęgniarki. Powstały również szkoły w Krakowie (1925 r.), Warszawie (1921 r.) i Poznaniu (1921 r.) $[4,12,14]$. W Krakowie funkcjonowała Uniwersytecka Szkoła Pielęgniarek i Opiekunek Zdrowia (Higienistek) - w skrócie USPiH. Organizatorkami szkoły były twórczynie i absolwentki Szkoły Zawodowych Pielęgniarek Stowarzyszenia PP. Ekonomek św. Wincentego a' Paulo. Cieszyła się akceptacją środowiska lekarskiego i poparciem profesorów Uniwersytetu Jagiellońskiego. Jako jedyna w Polsce (w tym czasie) funkcjonowała w ramach Wydziału Lekarskiego Uniwersytetu Jagiellońskiego. Kształciła w zakresie podstawowym, ale posiadała autonomiczne studium i własny statut. Uniwersytecka Szkoła Pielęgniarek była pierwszą polską szkołą pielęgniarstwa prowadzoną od samego początku 
wyłącznie przez polskie pielęgniarki. Szkoły w Warszawie (Warszawska Szkoła Pielęgniarstwa) i Poznaniu (Szkoła Pielęgniarstwa PCK) były prowadzone przez amerykanki - w Warszawie przez Helen Bridge (amerykanka, oddelegowana przez Międzynarodowy Czerwony Krzyż do utworzenia w Polsce szkolnictwa dla świeckich pielęgniarek), a w Poznaniu przez Itę Mac Donell (sprowadzoną do Polski przez Amerykański Czerwony Krzyż) [15].

Pod koniec XIX wieku powołano Międzynarodową Radę Pielęgniarek i rozpoczęła się era kształcenia pielęgniarek dyplomowanych - co było również zaczątkiem rozwoju polskiego pielęgniarstwa. Wraz z nią w rozwój pielęgniarstwa polskiego zaangażowane były takie organizacje, jak: Międzynarodowa Organizacja Czerwonego Krzyża, Amerykański Czerwony Krzyż oraz Fundacja Rockefellera oraz pielęgniarki dyplomowane z poza granic Polski, głównie ze Stanów Zjednoczonych. Wsparcie finansowe Fundacji Rockefellra, umożliwiało wyjazd polskim pielęgniarkom na stypendia zagraniczne. Wyjazdy stypendialne do krajów Ameryki Północnej i Europy Zachodniej pozwalały na uaktualnianie wiedzy oraz podnoszenie kwalifikacji zawodowych $[4,15,16]$.

W czasie II wojny światowej upadł cały system kształcenia, łącznie z pielęgniarstwem, okupant wyraził zgodę na kształcenie pielęgniarek jedynie w szkole w Warszawie, liczba osób, które zdobyły ten zawód znacząco spadła $[4,14,16]$. Warszawska Szkoła Pielęgniarstwa działała do wybuchu Powstania Warszawskiego, czyli do 1 sierpnia 1944 roku. Po wojnie konieczne było uzupełnienie braków pośród pielęgniarek, w związku z tym dopuszczono naukę zawodu poprzez kilkumiesięczne kursy - łącznie istniało 13 możliwości, aby zostać pielęgniarką. W 1945 r. wznowiła działalność szkoła pielęgniarska w Krakowie - USPiH. Powstała szkoła w Gdańsku (1945 r.), w Warszawie przy Zarządzie Głównym Związku Zawodowego Pracowników Służby Zdrowia (1947 r.). Liczba szkół szybko się zwiększała $[15,17]$.

Nastały czasy PRL-u, kiedy kształcenie było zróżnicowane. Do lat 50. XX wieku korzystano z przedwojennych systemów kształcenia. Powstawały szkoły asystentek pielęgniarskich, licea medyczne i szkoły pomaturalne $[3,4,5]$. Duże znaczenie w rozwoju pielęgniarstwa w Polsce miało założenie Polskiego Stowarzyszenia Pielęgniarek Zawodowych (1925 r.) Polskiego Towarzystwa Pielęgniarskiego w 1957 roku oraz Polskiego Stowarzyszenia Pielęgniarek Zawodowych. Ujednolicenie kształcenia w dziedzinie pielęgniarstwa było osiągalne dzięki Ustawie o rozwoju oświaty i systemu wychowania z 15.07.1961 [18]. Dzięki działalności Polskiego Towarzystwa Pielęgniarskiego było możliwie ustanowenie trzyletniego kształcenia pielęgniarek na Akademii Medycznej w Lublinie (1969 r.) oraz utworzenie tam Wydziału Pielęgniarskiego, który zainicjował współpracę z World Health Organization (WHO) [19]. Powstały wtedy: państwowe szkoły pielęgniarstwa ogólnego 2-letnie po maturze, państwowe szkoły pielęgniarstwa neuropsychiatrycznego 2 i pół-letnie po ukończeniu 9 klas szkoły podstawowej, licea medyczne pielęgniarstwa 5-letnie po ukończeniu 7 klas szkoły podstawowej, licea medyczne pielęgniarstwa 4-letnie po ukończeniu 9 klas szkoły podstawowej, licea medyczne pielęgniarstwa 3-letnie dla pracujących asystentek pielęgniarstwa [20].
Wśród aktywnych zawodowo pielęgniarek i pielęgniarzy najniższy poziom wykształcenia mają osoby, które ukończyły liceum medyczne [13]. Początkowo okres kształcenia w liceum trwał 4 lata, a od 1965 roku 5 lat $[4,10,16]$. Do liceum mogli się dostać kandydaci po ukończeniu szkoły podstawowej. Nauczanie pielęgniarstwa odbywało się na poziomie liceów medycznych do początku lat 90. XX wieku, kiedy zdecydowano o ich zamknięciu i nauczaniu zawodu w ramach szkół policealnych.

Powstanie Medycznych Studiów Zawodowych umożliwiało nauczanie zawodu po ukończeniu liceum ogólnokształcącego (do 1981 r., wymagano od kandydatów świadectwa dojrzałości). Od roku 1991/1992 pięcioletnie szkoły pielęgniarskie przestały zapisywać uczniów [11]. Od 1993 roku, w związku z planowanym przystąpieniem Polski do UE, rozpoczęto zmianę systemu edukacji w zawodach pielęgniarki i położnej tak, by dostosować polskie prawo do dyrektyw unijnych [21]. Doprowadziło to do powstania kilku innych wydziałów pielęgniarstwa na akademiach medycznych/ uniwersytetach: w Lodzi (1997), Bydgoszczy (1998), Gdańsku (1999), Białystoku (1999), Warszawie (2000) i Szczecinie (2001). Nowo utworzone jednostki akademickie oferowały programy magisterskie dla kandydatów, którzy ukończyli studia pielęgniarskie po ukończeniu podstawowego etapu edukacji [22].

Osoby, które zdobyły tytuł zawodowy, przed wprowadzeniem nauczania na poziomie studiów I stopnia, miały możliwość uzyskania tytułu licencjata, kończąc studia pomostowe $[3,4,5,10,16]$.

\section{Aktualne kształcenie w dzidzinie pielęgniarstwa na poziomie podstawowym w Polsce}

Polskie pielęgniarstwo doznaje ciągłych zmian w zakresie kształcenia pielęgniarek. Dzisiejsze pielęgniarstwo w Polsce jest ambitne, dynamicznie się rozwija. Tutaj usunięcie

Aktualnie tytuł pielęgniarki lub pielęgniarza można uzyskać kończąc trzyletnie studia licencjackie - (studia I stopnia) na kierunku pielęgniarstwo [23]. W obowiązek pielęgniarki wpisana jest ciągła edukacja i rozwój. W zawodzie tym konieczne jest stałe aktualizowanie swojej wiedzy $[6,23]$. Możliwa jest kontynuacja kształcenia na poziomie studiów II stopnia - magisterskich oraz studiów doktoranckich. Kolejnym etapem doskonalenia zawodowego jest kształcenie podyplomowe $\mathrm{w}$ formie specjalizacji, kursów kwalifikacyjnych, specjalistycznych czy doszkalających [23, 24]. Kształcenie podyplomowe jest dostępne dla każdej pielęgniarki i pielęgniarza, bez względu na stopień posiadanego wykształcenia. Zgodnie z art. 67 ust. 1 ustawy z dnia 15 lipca 2011r. o zawodach pielęgniarki i położnej - Dz. U. z 2018r. poz. 123 z późn. zm. - [6] pielęgniarka może uzyskać tytuł specjalisty w dziedzinie pielęgniarstwa biorąc udział w szkoleniu specjalizacyjnym (specjalizacji) zakończonym pozytywnie napisanym egzaminem państwowym. Tytuł specjalisty [25] pielęgniarstwa uzyskuje się kończąc szkolenie specjalizacyjne trwające 15 do 20 miesięcy, które ma na celu pozyskanie przez pielęgniarkę lub pielęgniarza specjalistycznej wiedzy i umiejętności w konkretnej dziedzinie medycznej. 
Aby uzyskać tytuł zawodowy pielęgniarki niezbędne jest ukończenie studiów licencjackich. Zgodnie z obowiązującymi standardami w Polsce kształcenie na kierunku pielęgniarstwo i położnictwo $\mathrm{w}$ ramach studiów licencjackich powinno trwać co najmniej 6 semestrów (3 lata). Liczba godzin zajęć praktycznych wraz z praktykami zawodowymi musi wynosić co najmniej 4720 , a liczba punktów ECTS powinna wynosić minimum 180 [23].

Studia pierwszego stopnia obejmują edukację z następującego zakresu [23]:

- nauk podstawowych: anatomia, fizjologia, patologia, genetyka, biochemiai biofizyka, mikrobiologia i parazytologia, farmakologia, radiologia;

- nauki społeczne i humanistyczne: psychologia, socjologia, pedagogika, prawo medyczne, zdrowie publiczne, jezzy angielski;

- nauk w zakresie podstaw opieki pielęgniarskiej: podstawy pielegniarstwa, etyka zawodu pielegniarki, promocja zdrowia, podstawowa opieka zdrowotna, dietetyka, organizacja pracy pielegniarskiej, badanie fizykalne, zakażenia szpitalne, system informacji w ochronie zdrowia, zajęcia fakultatywne do wyboru: język migowy lub wspótpraca w zespotach opieki zdrowotnej;
- nauki w zakresie opieki specjalistycznej: choroby wewnętrzne i pielegniarstwo internistyczne, pediatria i pielegniarstwo pediatryczne, chirurgia i pielegniarstwo chirurgiczne, położnictwo, ginekologia i pielegniarstwo położniczo-ginekologiczne, psychiatria i pielegniarstwo psychiatryczne, anestezjologia i pielegniarstwo w zagrożeniu życia, pielegniarstwo opieki dlugoterminowej, neurologia i pielegniarstwo neurologiczne, geriatria i pielegniarstwo geriatryczne, opieka paliatywna, podstawy rehabilitacji, podstawy ratownictwa medycznego, badania naukowe $w$ pielegniarstwie, seminarium dyplomowe.

Studia licencjackie na kierunku pielęgniarstwo kończą się egzaminem dyplomowym (teoretycznym i praktycznym) oraz napisaniem pracy licencjackiej $[8,23,24]$.

\section{Różnice w kształceniu pielęgniarek w zakresie podstawowym}

Kształcenie w dziedzinie pielęgniarstwa zmieniało formę przez lata. Przedmioty nauczane w ramach liceum medycznego, medycznego studium zawodowego (pomaturalnego lub policealnego) czy studiów licencjackich różnią się między sobą. Przedmioty jakich nauczano

Tab. 1. Wykaz przedmiotów nauczanych w liceach medycznych, w latach 1984-1989 na podstawie Liceum Medycznego w Tychach oraz w latach 1980-1985 na podstawie Liceum Medycznego w Katowicach [26]

\begin{tabular}{|c|c|c|}
\hline Zakres nauczania & $\begin{array}{c}\text { Wykaz przedmiotów } \\
\text { (na przykładzie Liceum Medycznego w Tychach) }\end{array}$ & $\begin{array}{c}\text { Wykaz przedmiotów } \\
\text { (na przykładzie Liceum Medycznego w Katowicach) }\end{array}$ \\
\hline Nauki podstawowe & $\begin{array}{l}\text { - anatomia i fizjologia, } \\
\text { - nauka o lekach, } \\
\text { - patologia, } \\
\text { - biologia z mikrobiologia, }\end{array}$ & $\begin{array}{l}\text { - anatomia, } \\
\text { - zarys nauk o lekach, } \\
\text { - patologia, }\end{array}$ \\
\hline Nauki społeczne & $\begin{array}{l}\text { - podstawy psychologii, pedagogiki i socjologii; } \\
\text { - psychologia; }\end{array}$ & $\begin{array}{l}\text { - psychologia i pedagogika, } \\
\text { - psychologia, }\end{array}$ \\
\hline $\begin{array}{l}\text { Nauki w zakresie podstaw opieki } \\
\text { pielęgniarskiej }\end{array}$ & $\begin{array}{l}\text { - pielęgniarstwo ogólne } \\
\text { - pracownia pielęgniarstwa; } \\
\text { - higiena i żywienie; } \\
\text { - choroby zakaźne; } \\
\text { - choroby skóry i weneryczne; } \\
\text { - zagadnienia zawodowe; }\end{array}$ & $\begin{array}{l}\text { - pielęgniarstwo ogólne, } \\
\text { - pracownia pielęgniarska, } \\
\text { - ćwiczenia pielęgniarskie, } \\
\text { - higiena żywienia z ćwiczeniami, } \\
\text { - choroby zakaźne, } \\
\text { - choroby skóry i weneryczne, } \\
\text { - organizacja ochrony zdrowia, } \\
\text { - zagadnienia zawodowe, } \\
\text { - higiena ogólna, szkolna, przemysłowa, }\end{array}$ \\
\hline $\begin{array}{l}\text { Nauki w zakresie podstaw opieki } \\
\text { specjalistycznej }\end{array}$ & $\begin{array}{l}\text { - choroby wewnętrzne; } \\
\text { - chirurgia, transplantologia i pomoc doraźna, } \\
\text { - pielęgniarstwo w chorobach wewnętrznych, } \\
\text { - zblokowane zajęcia praktyczne, } \\
\text { - chirurgia, transfuzjologia i pomoc doraźna; } \\
\text { - medycyna wieku rozwojowego; } \\
\text { - położnictwo i choroby kobiece, } \\
\text { - choroby nerwowe i psychiczne, } \\
\text { - pielęgniarstwo chirurgiczne, } \\
\text { - pielęgniarstwo położnicze i ginekologiczne, } \\
\text { - pielęgniarstwo w lecznictwie otwartym, } \\
\text { - pielęgniarstwo neurologiczne, } \\
\text { - neurologia, }\end{array}$ & $\begin{array}{l}\text { - zblokowane zajęcia praktyczne, } \\
\text { - pielęgnowanie w chorobach chirurgicznych, } \\
\text { - pielęgnowanie położnicze, } \\
\text { - chirurgia, } \\
\text { - pielęgnowanie dzieci, } \\
\text { - pediatria, } \\
\text { - położnictwo i ginekologia, } \\
\text { - choroby nerwowe i psychiczne, } \\
\text { - psychiatria, } \\
\text { - pielęgniarstwo neuropsychiatryczne, } \\
\text { - interna, } \\
\text { - pielęgniarstwo wewnętrzne, } \\
\text { - pielęgniarstwo w otwartej opiece zdrowotnej, }\end{array}$ \\
\hline Język obcy & $\begin{array}{l}\text { - język łaciński, } \\
\text { - język rosyjski. }\end{array}$ & $\begin{array}{l}\text { - język łaciński } \\
\text { - język niemiecki. }\end{array}$ \\
\hline
\end{tabular}

Opracowanie własne na podstawie: Świadectwa szkolne Liceum Medycznego w Tychach z lat 1984 - 1989 oraz Świadectwa szkolne Liceum Medycznego w Katowicach z lat 1980-1985 [27]. 
Karolina Pradela, Zuzanna Radosz, Agnieszka Sobiegała

w ramach liceów medycznych odróżniają się od nauczanych obecnie w ramach studiów licencjackich, a dodatkowo różnią się one pomiędzy poszczególnymi liceami (Tab. 1). Przedmioty, takie jak: psychologia, pedagogika i socjologia, które są nauczane w ramach studiów licencjackich jako osobne przedmioty, w liceum medycznym były scalone jako jeden przedmiot: podstawy psychologii, pedagogiki i socjologii, a w niektórych liceach obejmowały tylko przedmiot psychologia i pedagogika, bez socjologii. Nauczanie w zakresie opieki specjalistycznej także odbiega od siebie. Przedmioty z zakresu nauk podstawowych również nie są takie same w różnych liceach, a zdecydowanie różnią się one od tych nauczanych aktualnie w ramach studiów I - stopnia. Nauczanie w ramach liceum medycznego nie obejmowało edukacji z zakresu: fizjologii - był to jeden przedmiot anatomia i fizjologia oraz parazytologii. Dodatkowo nie nauczano genetykii, biochemii i biofizyki oraz radiologii. Mikrobiologii nauczano w ramach przedmiotu biologia z mikrobiologią, ale nie wszędzie.

Kształcenie w ramach medycznego studium zawodowego (Tab. 2) podobnie jak w liceach medycznych nie dorównuje w zakresie nauk społecznych aktualnie obowiązującym standardom kształcenia. Przedmioty takie jak psychologia i socjologia znajdowały się w programie kształcenia, jednak nie obejmowały nauczania w zakresie pedagogiki, zdrowia publicznego, filozofii czy etyki zawodu pielęgniarki. Nie nauczano dietetyki, która była prowadzona w liceum medycznym jako higiena i żywienie. Podobnie jak w liceum medycznym program kształcenia nie obejmował parazytologii, genetyki, biochemii i biofizyki. Nauczano jednak mikrobiologii, prawa czy łaciny.

Klapa i wsp. [28] w swojej pracy zwracają uwagę na modyfikację kształcenia humanistycznego w ramach kierunku pielęgniarstwo, głównie pedagogiki, która nie była nauczana przed wprowadzeniem kształcenia na poziomie licencjata w uczelniach wyższych. Pielęgniarka w pracy ma spełniać rolę nie tylko opiekuńczo - leczniczą czy pielęgnacyjną. Do zadań pielęgniarki należy również promocja zdrowia, edukacja zdrowotna, praca z młodzieżą, prowadzenie kursów i szkoleń, a także wspieranie psychologiczne i pedagogiczne pacjentów i ich rodzin [28]. Pielęgniarka posiada również wiedzę z zakresu nauk humanistycznych - społecznych, np. andragogiki, pedagogiki, psychologii, socjologii [29]. Można wnioskować, że pielęgniarki, które ukończyły pielęgniarstwo w ramach studiów licencjackich są lepiej przygotowane do pełnienia roli wychowawczej i edukacyjnej od pielęgniarek kształcących się w latach ubiegłych w ramach innego toku nauczania.

W ramach edukacji w poprzednich systemach kształcenia (tj. Liceum medyczne, Medyczne Studium Zawodowe) na kierunku pielęgniarstwo większą uwagę zwracano na wygląd kandydatek na pielęgniarki. Uczennice nie mogły mieć pomalowanych paznokci, włosy musiały być upięte, mundurki wszystkie uczennice w jednej klasie musiały mieć takie same, dodatkowo konieczne było noszenie czepka pielęgniarskiego [30]. Obecnie nie ma wymogów odnośnie jednakowego umundurowania, noszenie czepka również nie jest obowiązkowe.
Tab. 2. Wykaz przedmiotów nauczanych, w latach 1990-1992 na podstawie Medycznego Studium Zawodowego $\mathrm{Nr} 3$ w Katowicach [31]

\begin{tabular}{|c|c|}
\hline Zakres nauczania & Wykaz przedmiotów \\
\hline Nauki podstawowe & $\begin{array}{l}\text { - farmakologia, } \\
\text { - mikrobiologia, } \\
\text { - anatomia, } \\
\text { - patologia, }\end{array}$ \\
\hline Nauki społeczne & $\begin{array}{l}\text { - socjologia, } \\
\text { - psychologia, } \\
\text { - higiena, bezpieczeństwo i prawo pracy }\end{array}$ \\
\hline $\begin{array}{l}\text { Nauki w zakresie podstaw opieki } \\
\text { pielęgniarskiej }\end{array}$ & $\begin{array}{l}\text { - choroby skóry i weneryczne, } \\
\text { - pielęgniarstwo ogólne, } \\
\text { - pracownia pielęgniarska, } \\
\text { - organizacja ochrony zdrowia } \\
\text { - higiena, bezpieczeństwo i prawo pracy } \\
\text { - pielęgniarstwo w otwartej opiece zdrowotnej, }\end{array}$ \\
\hline $\begin{array}{l}\text { Nauki w zakresie podstaw opieki } \\
\text { specjalistycznej }\end{array}$ & $\begin{array}{l}\text { - choroby wewnętrzne, } \\
\text { - pielęgniarstwo wewnętrzne, } \\
\text { - chirurgia, } \\
\text { - pielęgniarstwo chirurgiczne, } \\
\text { - choroby nerwowe i psychiczne, } \\
\text { - pielęgniarstwo neurologiczno-psychologiczne, } \\
\text { - położnictwo i choroby kobiece, } \\
\text { - medycyna wieku rozwojowego, } \\
\text { - pielęgniarstwo położniczo-ginekologiczne }\end{array}$ \\
\hline Język obcy & - język łaciński. \\
\hline
\end{tabular}

Opracowanie własne na podstawie: Indeks Medycznego Studium Zawodowego $\mathrm{Nr} 3$ w Katowicach z lat: 1990-1992 [31].

Edukacja w dziedzinie pielęgniarstwa przez lata była różnorodna. Różnice w zakresie podstawowym obejmowały poziom posiadanego wykształcenia: średnie, wyższe; czas edukacji na kierunku pielęgniarstwo oraz czas edukacji poprzedzającej. Edukacja w liceum medycznym trwała początkowo 4 , a potem 5 lat, przy czym obejmowała ona również edukację przedmiotów ogólnokształcących równolegle z zawodowymi $[6,23]$. Nauczanie w ramach szkoły policealnej bądź pomaturalnej obejmowało: 2; 2,5 lub 3 lata $[13,14]$. Obecnie edukacja musi trwać co najmniej 3 lata (6 semestrów). Różnice pojawiają się również $\mathrm{w}$ aspekcie godzin nauki. Obecnie jest to minimum 4720 godzin [23]. W latach nauczania pielęgniarstwa na poziomie licealnym był to zakres godzin: 4256 do 3078 w zależności od roku. Natomiast na poziomie policealnym (3-letnim) były to 4344 godziny. Najmniejszą liczbę godzin obejmowała edukacja 2-letnia na poziomie policealnym $[13,14]$. Liczba godzin przeznaczona na kształcenie teoretyczne na poziomie liceum, trzyletniego studium medycznego i studiów licencjackich jest podobna. Różni się ona w przypadku szkół 2 i 2,5 - letnich. Kształcenie praktyczne (praktyki zawodowe, zajęcia kliniczne, zajęcia praktyczne) także było odmienne w różnych systemach kształcenia - w liceum medycznym obejmowało ono od 2242 do 1715 godzin, a w ramach studium medycznego było to od 1400 do 1715 godzin [25, 28]. Aktualnie $\mathrm{w}$ ramach studiów I stopnia zajęcia praktyczne wraz z praktykami zawodowymi obejmują 2300 godzin [14].

Różnice w programach edukacji, które obowiązywały w różnych latach są widoczne na przykładzie studiów pomostowych - licencjackich uzupełniających. Miały 
one na celu uzupełnienie wykształcenia pielęgniarek i umożliwienie im zdobycia tytułu licencjata. Dotyczy to pielęgniarek, które zdobyły tytuł zawodowy pielęgniarki kończąc szkoły o innej specyfice. Niezbędnym warunkiem do przyjęcia na studia pomostowe było posiadanie matury. Program studiów uzupełniających był zależny od roku i rodzaju ukończonej szkoły $[5,8]$. Pielęgniarki, które posiadają wykształcenie wyższe (licencjackie lub magisterskie) bardziej doceniają i rozumieją swoją autonomię zawodową. Widzą również większe możliwości w osiągnięciu rozwoju zawodowego, które ma wpływ na poprawę opieki nad pacjentem [32].

Duże możliwości dla rozwoju polskiego pielęgniarstwa daje finansowanie z Unii Europejskiej grantów. Możliwe jest również otrzymanie dotacji naukowych. Takim przykładem jest projekt EuropeanRancare COST [33]. Warto również zwrócić uwagę na ogólny rozwój medycyny, a co za tym idzie pielęgniarstwa. Nowoczesne szpitale, e-zdrowie to elementy, które także wpływają na kierunek rozwoju pielęgniarstwa i kształcenia zawodowego pielęgniarek [26].

Jeżeli mowa o rozwoju polskiego pielęgniarstwa, koniecznie jest „dalekowzroczne” myślenie i zarządzanie co podkreślają liderzy [34]. Ważne jest opracowanie strategii badań naukowych w pielęgniarstwie, co się przekłada na jakość kształcenia i ma daleko sięgające efekty [35].

\section{WNIOSKI}

1. Na przestrzeni lat system kształcenia pielęgniarek w zakresie podstawowym bardzo się zmienił.

2. Wiedza pielęgniarek oraz ich samodzielność zawodowa zwiększyła się.

3. W edukacji pielęgniarek nadal kładzie się nacisk na praktyczną naukę zawodu.

\section{REFERENCES/PIŚMIENNICTWO}

1. Komunikat z badań CBOS. Które zawody poważamy? Dostępny online: https://www cbos.pl/SPISKOM.POL/2019/K_157_19.PDF Data dostępu: 20.02.2020

2. Golinowska S, Kocot E, Sowa A. Human resources in healthcare. Up-to-datetrends and projections. Zdrowie Publiczne i Zarządzanie. 2013;11:125-147.

3. Renn-Żurek A. Interdyscyplinarny wymiar pielęgniarstwa. Ewaluacja kształcenia pielęgniarek i położnych. Wydawnictwo Akademii Humanistyczno Ekonomicznej w Łodzi; Łódź 2018, 5-9.

4. Phillips JM, Stalter AM. Integrating Systems Thinking Into Nursing Education. The Journal of ContinuingEducation in Nursing. 2016; 47 (9): 395-397.

5. Rozporządzenie Ministra Nauki i Szkolnictwa Wyższego z dnia 9 maja 2012 r. w sprawie standardów kształcenia dla kierunków studiów: lekarskiego, lekarskodentystycznego, farmacji, pielęgniarstwa i położnictwa. Dziennik Ustaw 2012, pos.631. Dostepny online: isap.sejm.gov.pl/DetailsServlet?id=WDU20120000631. Data dostępu: 20.02.2020

6. Rozporządzenie Ministra Zdrowia z dnia 14 czerwca 2012 r. w sprawie szczegółowych warunków prowadzenia studiów dla pielęgniarek i położnych, które posiadają świadectwo dojrzałości i ukończyły liceum medyczne lub szkołę policealną albo szkołę pomaturalną, kształcącą w zawodzie pielęgniarki i położnej (Dz.U. 2012 poz. 770 ).

7. Kózka M, Wrońska I, Kądalska E, Van Damme-Ostapowicz A. Europejskie kształcenie pielęgniarek. [w:] Wrońska I, Krajewska-Kułak E. (red.), Wybrane zagadnienia z pielęgniarstwa europejskiego. Lublin: Czelej; Lublin (in Polish). 2007.

8. Ciechaniewicz W. Pedagogika. Warszawa: Wydawnictwo Lekarskie PZWL. 2008: 180-181, 276-278.

9. Solorz T. Zmiany akademickiego systemu kształcenia pielęgniarek i położnych w Polsce w latach 1969-2009. Studium historyczno - edukacyjne. Uniwersytet Medyczny im. Karola Marcinkowskiego w Poznaniu Wydział Nauk o Zdrowiu. Praca doktorska; Poznań 2014: 26-27, 37-43, 49-54.

10. Solorz T. Kształcenie zawodowe pielęgniarek w ujęciu historycznym. Polski Przegląd Nauk o Zdrowiu 2014; 4 (41): 298-304.
11. Wierzbicka I. Nursing - history and development of the profession. Journal of Education, Health and Sport. 2019; 9(9):121-129.

12. Karimi H, MasoudiAlavi N. Florence Nightingale: The Mother of Nursing. Nursing and Midwifery Studies. 2015; 4(2): e29475.

13. Kolasińska J, Gajek J, Panaszek B. Podobieństwa i różnice systemów kształcenia przeddyplomowego pielęgniarek w Polsce w latach 1945 - 2016 w aspekcie zasad obowiązujących w Unii Europejskiej. 2017: Dostępny online: http://phf.medlist. org/2018/04/24/04_2017_01/Data dostępu: 13.02.2019

14. Rasińska R, Nowakowska I, Bańkowska A. Proces kształcenia pielęgniarek i położnych w świetle wybranych danych statystycznych. Pielęgniarstwo Polskie 2017; (64) 2017: 334-337.

15. Kaniewska-lżycka J. Rozwój pielęgniarstwa w Polsce do roku 1950. Cz. II. Centrum Metodyczne Doskonalenia Nauczycieli i Średniego Szkolnictwa Medycznego, Warszawa 1988; 28-31.

16. Wrońska I. red. Polskie Pielęgniarstwo 1921-1939. Norbertinum; Lublin 1991, 31-37.

17. Majda A, Zalewska-Puchała J. Stuletnia tradycja kształcenia pielęgniarek w Krakowie. Problemy Pielęgniarstwa. 2012; 20 (1): 92-101.

18. Marć M, Binkowska-Bury M, Penar-Zadarko B. Wymagania stawiane nauczycielom zawodu pielęgniarstwa - przeszłość, teraźniejszość, przyszłość. Problemy Pielęgniarstwa. 2008; 16 (4): 405-408.

19. Ślusarska B, Zarzycka D, Dobrowolska B, et al. Nursing education in Poland - The pastand new development perspectives. Nurse Education in Practice. 2018; 31:118-125.

20. Fetlińska J. Kształtowanie się wyższego szkolnictwa pielęgniarskiego. W: Urbanek B, red. Zawód pielęgniarki na ziemiach polskich w XIX i XX wieku. Warszawa: Wyd. Makmed, 2008. s. 407-408.

21. Łukasz-Paluch K, Franek G. Ruch zawodowy i przemiany w kształceniu podstawowym pielęgniarek na przełomie wieków. Problemy Pielęgniarstwa. 2008; 16 (1,2): 173-180.

22. Majda A, Ziarko E, Zalewska-Puchała J. A consistent course of events or a series of coincidences: nursing in Poland from the 19th to the 21st century. Nursing Inquiry. 2015; 22(4): 359-370.

23. Rozporządzenie Ministra Nauki i Szkolnictwa Wyższego z dnia 26 lipca 2019 r. w sprawie standardów kształcenia dla kierunków studiów: lekarskiego, lekarskodentystycznego, farmacji, pielęgniarstwa i położnictwa. (Dz.U. 2019 poz. 1573).

24. Rozporządzenie Ministra Zdrowia z dnia 12 grudnia 2013 r. w sprawie wykazu dziedzin pielęgniarstwa oraz dziedzin mających zastosowanie w ochronie zdrowia, w których może być prowadzona specjalizacja i kursy kwalifikacyjne (Dz.U. 2013 poz. 1562).

25. Rozporządzenie Ministra Zdrowia z dnia 30 września 2016 r. w sprawie kształcenia podyplomowego pielęgniarek i położnych (Dz.U. 2016 poz. 1761).

26. Mędrzycka-Dąbrowska W, Sebastian D, Andrzej B. Perception of barriers to postoperative pain management in elderly patients in Polish hospitals a multicenter study. Journal of Nursing Management. 2016; 24(8):1049-1059.

27. Świadectwa szkolne Liceum Medycznego w Tychach z lat 1984-1989 oraz Świadectwa szkolne Liceum Medycznego w Katowicach z lat 1980-1985 - dokument własny.

28. Klapa W, Zych B, Oskędra I, Orzeł A. Kilka uwag o pedagogicznym kształceniu pielęgniarek w toku studiów licencjacko - magisterskich. Wyzwania współczesnego pielęgniarstwa. 2000 (30): 89-93.

29. Rżewska I. Społeczne problemy zawodu pielęgniarki. Instytut wydawczy CRZZ. Warszawa 1973: 40-3, 70-73, 104-108.

30. Maksymowicz A. Organizacja i metodyka pracy wychowawczej w szkole pielęgniarstwa. Państwowy Zakład Wydawnictw Lekarskich. Warszawa 1980: 9, 47-52, 85.

31. Indeks Medycznego Studium Zawodowego Nr 3 w Katowicach z lat: 1990-1992 dokument własny.

32. Brayer A, Foley M, Doroszkiewicz A, et al. Job satisfactionamongmasters in nursingin central and east poland: a preliminarystudy. Family Medicine and PrimaryCareReviewJournal. 2017; 19(1): 7-11.

33. Belowska B, Iwanow L, Uchmanowicz I, Gotlib J. Rancare Rationing MissedNursingCare: An International And Multidimensional Problem - Report On The First Training At Annual Training School - 2017 In Turku (Finland). 2018. Dostępny online: https://doi.org/10.20883/pielpol.2018.28Data dostępu: 20.02.2020

34. Ministry of ForeignAffairs/Netherlands Enterprise Agency (2017) Polish Healthcare SectorAligning Dutch Smart Solutions to Polish0pportunities. Task Force Healthcare: The Netherlands. Dostepny online: https://www.tfhc.nl/wp-content/ uploads/2017/12/ TFHC-Market-Study-Poland-2017.pdf

35. Kosińska M, Niebrój L. The position of a leader nurse. Journal of Nursing Management. 2003; 11: 69-72.

Manuscript received/Praca zgłoszona do czasopisma: 06.11.2019

Manuscript accepted/Praca zaakceptowana do druku: 02.03.2020

Translation/Tłumaczenie: Let’s GO Jerzy Wąsik 